\title{
Commodification of Children in Popular Culture: Critical Discourse Analysis of Idola Cilik Singing Contest Program on Local Television in Indonesia
}

\author{
Yunita Sari \\ Universitas Prof. Dr. Moestopo (Beragama) \\ Jakarta, Indonesia \\ yunitasari286.ys@gmail.com
}

\begin{abstract}
This paper presents an analysis of performance and commodification of children in "Idola Cilik" singing contest on Indonesian Television program (RCTI) through textual analysis. It is aimed to determine the background of its production and capitalism that turn the use value into exchange value on RCTI's "Idola Cilik" program through social cognition analysis, and to find out the interpretation of the Chairman of National Commission for Child Protection on "Idola Cilik" singing contest through social context. This study applies qualitative research method of Van Dijk's critical discourse analysis, including textual, social cognition and social context analysis. The results showed that: (1) From analysis of the text, the performance and the commodification of children in the "Idola Cilik" program are actually the result of television media industry; (2) From analysis of social cognition, RCTI's "Idola Cilik" program is created due to the lack of special programs for children; (3) Based on the analysis of social context, "Idola Cilik" has generated positive interpretations. Therefore, through this study, the producers of children programs are expected to be more concerned about the compatibility of program contents, and to pay much attention to the psychology of children, by putting the children not merely as some commodity to gain huge profit. As for the parents, they should be more selective on choosing TV programs for their children. Moreover, parents are also advised not to exploit their children by forcing them to be TV stars.
\end{abstract}

Keywords: Commodification of children; Capitalism; Television Industry; Popular Culture

\section{Introduction}

As a mass medium, television has several advantages that make it one of viewers' favorite. Physically, like any other mass media, the presence of television can affect society. The physical presence of mass media will bring some effects such as the economic effect, social effect, the effect on scheduling of activities, the effect on distribution/elimination of certain feelings and the effect of a person's feeling towards media. A number of researches show that duration of children's television viewing has increased from year to year.

Evens and Donders [1] presented challenges for competition, industrial and media policy over perspective on the regulation of M\&A in the TV industry. Oh et al. [2] explored a new issue on TV show recommendation. Ansari and Crosnoe [3] presented Children's hyperactivity, television viewing, and the potential for child effects. Li, et al. [4] presented Children's knowledge about the reality status of fantastical events in television. Lin, et al. [5] explored the Effects of television exposure on developmental skills among young children. Murphy [6] presented Design Capitalism in the AutoIndustrial Age. Renner [7] presented Film and Popular Culture. Michalis and Smith [8] explored Lessons from the regulation of television distribution. Dunsmore and Haspel [9] 
presented a case study of reality-based television discourse. Evens and Donders [10] presented Television distribution: Economic dimensions, emerging policies. Gordon [11] explored Impression management on reality TV. Indonesian Child Welfare Foundation notes that currently, the average of television viewing of elementary school-age children is 30 to 35 hours per week. It means that during regular days, the children spend more than four or five hours per day watching television. Meanwhile, on Sundays, they even spend seven until eight hours, even though there are so many unsafe TV shows for the children (newspaper: Media Indonesia, 2006, "Program Televisi Anak-anak Menonton Lima Jam Sehari," Jakarta). The domination of pro-market shows is one of the main reasons that diminish the positive side of television.

Television as a media has the main role and ideal purpose to be the agent of communication, culture, and intelligence and to educate the mental of the people marginalized by profit-seeking interests. This condition is reflected in a talent show on television. Actually, this talent show is not a new one. In TVRI's Indonesia era, there was a well-known show called "Lagu Pilihanku" A couple of years ago, Indosiar (Indonesia private television station) held "AFI Junior," a singing contest for children following the success of AFI (Indosiar Fantasy Academy). The Indosiar also broadcasts another show called "Masuk Tivi". Furthermore, RCTI (Indonesia private television station) also broadcasts a show called "Idola Cilik" every day in a week. As suggested by its name, the singing contest is aimed for 7-to-12-year-old children. The selected contestants of Idola Cilik will be given several trainings such as choreography, vocal, performance, personality, and fashion. All selected contestants of Idola Cilik will compete every week on Idola Cilik stage. The performances will be commented by some juries, among others, Ira Maya Sopha, Winda Viska Ria, Duta of Sheila on 7, and Dave Hendrick. The viewers can give their supports via SMS. Unfortunately, this show is often presented in a less suitable format for children.

Study about children world in media, particularly singing contest, is important because the portrait of Indonesia in the future can be partly predicted based on what the children consume from media, particularly television oriented to capital accumulation and expansion. This study aims to identify:

a. The performance and commodification of children in Idola Cilik singing contest on RCTI, through textual analysis.

b. The background of the production process and capitalism behind the process of commodification in Idola Cilik on RCTI, through social cognition analysis.

c. The interpretation of the Chairman of National Commission for Child Protection and communication experts concerning Idola Cilik, through social context.

The rest of this paper is organized as follow: Section 2 describes the data used and proposed method. Section 3 describes 3. Result and Discussion. Finally, the conclusion of this work is described in Section 4.

\section{Data \& Methodology}

This section describes the data used and proposed method.

\subsection{Data}

The data used in this study is recording of Pentas Idola Cilik 2 (2009) and Rapor Idola Cilik 2 as well as other secondary data, i.e. the profiles of RCTI and Idola Cilik program. The informants include: Executive Producer of the program, Programming and Scheduling Division of RCTI, the Chairman of National Commission for Child Protection, communication experts and the head of Children Media Development Foundation. 


\subsection{Method}

This study applies critical paradigm, that mass media are comprehended as a whole production process and a social structure. One of the relevant approaches in the context of mass media in the critical paradigm is political economy approach. It is presumed that this political economy grows in the private television stations in Indonesia and affects the existence of television to set the standards of programs in mass media. The method applied in this qualitative research is Van Dijk's critical discourse analysis involving three structures: text, social cognition, and societal (social context) Eriyanto [12]. The critical approach tries to uncover the process of domination by one group towards another in the conflictual relation. In practice, the critical approach is often used by marginalized groups in public interest. The steps performed in this study are as follows:

a. Textual level: it is directed to verbal texts on "Idola Cilik" singing contest.

b. Individual level: it is directed to discover individual interpretation towards the broadcasting of the children singing contest translated into the mechanism and standard of program production. The individuals are those who have access or experience in production, among others, the executive producer of Idola Cilik and the Programming and Scheduling Division of RCTI.

c. Organizational/institutional level: it is directed to the production process of Idola Cilik.

d. Societal: it is directed to see the relation between cultural production of messages on television and related discourse in the society through an interview with the Chairman of the National Commission on Children Protection and communications experts, as well as the head of Children Media Development Foundation.

The data is collected by analyzing the recording of Idola Cilik singing contest and by holding in-depth interviews with the key informants. Data validity is evaluated using data, theory and methodology triangulation.

\section{Result and Discussion}

The Idola Cilik is a talent show for children in a field of singing aired by RCTI TV station. It is a second biggest singing contest in Indonesia after Indonesian Idol. This program is addressed to 7-to-12-year-old children. It is a 4-hour-duration variety show. All selected contestants are given trainings such as choreography, vocal, performance, personality and fashion training. They will be competed on the stage every week and commented by commentators and supported by the viewers' text messages. It was begin with a unique production process called "Picking up the ball (Jemput Bola)", where RCTI searches the contestants of the audition by coming to the cities in Indonesia. Generally, on a program like this, many candidates actively come to the audition. Children's performance in this show is actually the reflection of their talent, particularly in singing. Talented child is a child identified as the one who has extraordinary skill and capable of achieving high achievement (Davis and Rimm 1998 in Gunarsa [13]. The reading of the variety show of Idola Cilik as children singing contest through critical discourse analysis has generated messages of communication such as narration, figures etc. That will be interpreted in the form of values, ideology, emotions, interests etc. In this study, textual reading is analyzed through the contestant's performance (image capture) and dialog. All genres have particular textual aspects or a set for the element of the text allowing the public to recognize a text in a particular genre or generic. The elements in a genre include narration, setting, characteristic, style, visual or aural signs (iconography sign), way of presentation (how text positions the society in accordance with demographic aspects such as age, sex or ethnic), and star (specifically for big screen) (Dunn, 2005 in Sunarto [14]. 
The author evaluates that what was presented by the Executive Producer of Idola Cilik is not entirely true, because there is a gap between direct practice (based on textual analysis of the show) and what has been spoken. There are many aspects deviated from the concepts of the program in the production, such as the selection of songs, costumes, makeup, and psychology of the contestant. The following are some examples of image captures of "Idola Cilik" program and explanations.

\section{Table 1. The Captures of Some Scenes of Idola Cilik Program}
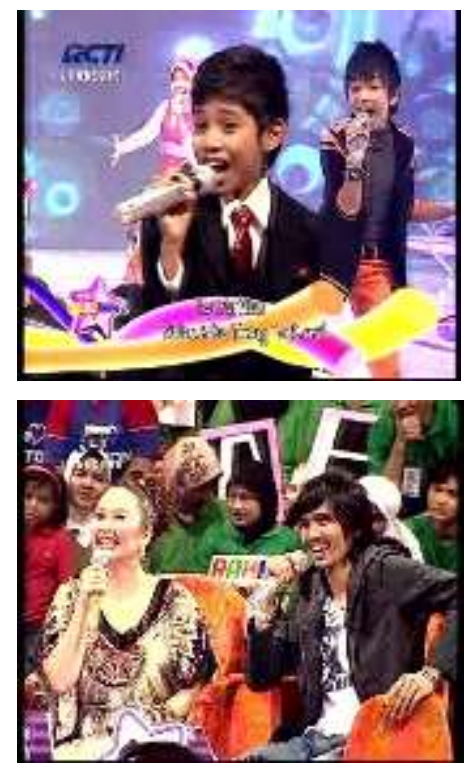

The performance of the contestant of Idola Cilik singing a song titled "Walau Habis Terang" by Ariel.

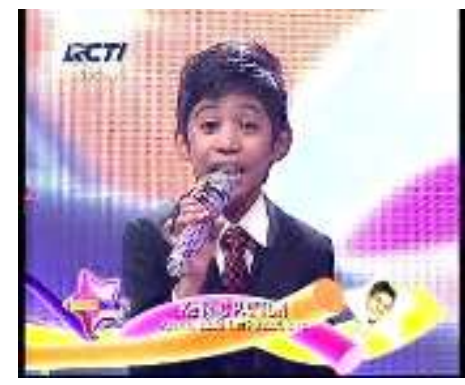

Ira Maya Sopha and Duta as the commentators of "Idola Cilik" comment on the performance of the contestant.

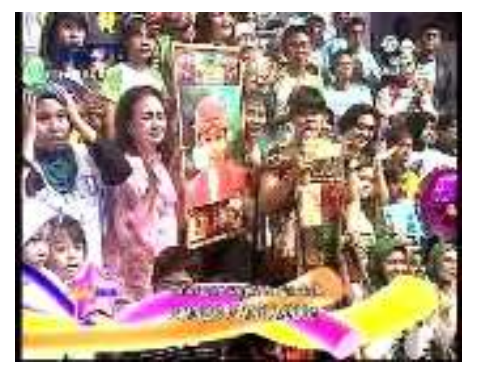

After the performance, the contestant will ask for public support through SMS, by saying "Ketik Patton" (the contestant's name), and send it to 6288 . The fare is IDR 2000/SMS.

The viewers in the studio consist of family and friends.

Commercial break, and etc.

The performance of the children in Idola Cilik program can be seen through images and dialog (textual). It is a form of verbal discourse transferred into meaningful text describing commodification through their performance. Several distinctive aspects that are supposed to give 'children' atmosphere to the program become inconsistent with the cheerful world of children. Commodification is a transformation process of use value into exchange value Mosco [15]. The process of commodification turns objects (commodity) into something with exchange value and turns work product into commodity when it is 
made for others to consume through special exchange, that is, market exchange. Children as commodity in Idola Cilik singing contest have similar characteristic with other commodity, i.e. they are the result of human labor, the labor of the production team. Therefore, the object of commodification in this study is children, who perform on stage by singing in order to please the viewers and fans in cultural context. The children sing in exchange for support by as much SMS voting as possible to actualize their dream to be Idola Cilik or children idols the idol, later facilitated by media in pop culture, is one of the ways for humans to express themselves. There are various ways of expressing one self. Performing or self-performing is a way for someone to become an idol. 4-hour-duration "Idola Cilik" and 2-hour-duration "Raport Idola Cilik" are categorized as time commodification that can be categorized as exploitation to television viewing for children. Thus, the program has commercialized children's time for television industry. Children exploitation on behalf of artistic value displayed in television is a form of commodification. Salary is the main purpose of media, as well as high rating. Therefore, there are many incoming commercials and unconsciously, many children and adults become the victims of media and being sold to advertisers. In regard of the viewers who send support through SMS, when they support the winners, they will get equal exchange in the form of money. The transformation is also a part of television industry. They produce a singing contest as a commodity to be commercialized to the viewers with the exchange value in the form of support for the contestant. The evaluation of the contestants by the commentators is associated with psychological condition of the contestants. They will be happy when they get positive comment, and will be depressed when they get negative comments, although their performance, from vocals, choreography, arrangement, to costumes is the setting of the production team. The contestants are no longer themselves, they belong to commentators, producers, supporters, commercial products, and definitely the parents. The unstable emotion of the contestants of Idola Cilik leads to depression. They keep wishing not to fail every week. There are fear, pride, embarrassment and guilt when they are eliminated; whereas, children are supposed to live without coercion. However, the contestants live in competition atmosphere that requires them to win in order to success.

In the aspect of the song, the children often sing an adult song that is not suitable for their age and self-development. The lyrics contain love, affair, etc. that are not suitable for children. It is similar to the selection of costume, choreography and guest star to brighten the program that are unsuitable for children and mostly arranged in an adult concept. The supporters in the studio are mostly from family members, ranging from teenagers to adults but no children of similar age. Thus, what really happens in this program is that the wheels of the entertainment business coloring or controlling the desire of parents and children to achieve success in the world of entertainment. Idola Cilik program is considered positive and suitable for children to develop their talent in singing. Through this program, the winner could change for a better life. After joining this contest, the children who start from nothing become different individuals with popularity and a number of new activities and new "possession" such as house, vehicle and others. The point is, by joining this contest, their life will change rapidly.

Figure 1 as follow depictures the production of the program, starting from the preproduction, production and post-production based on the social cognition analysis of the executive producer of "Idola Cilik" in RCTI. 


\section{PRE-PRODUCTION}
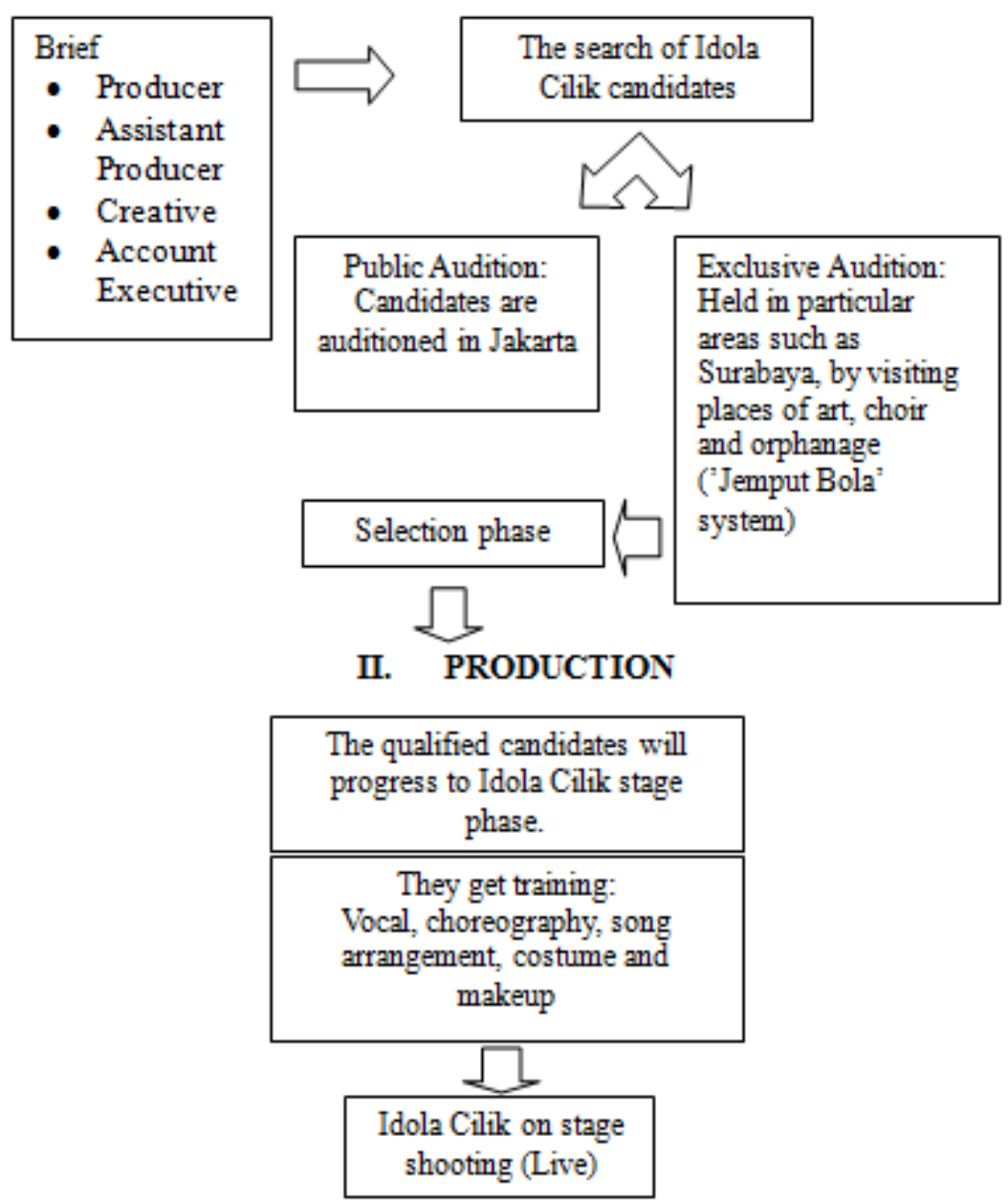

III. POST-PRODUCTION

Program Evaluation

\section{Figure 1. The Process of Production (Source: Data Analysis Processed by the Author)}

From Figure 1 and based on the social cognition of programming division, it can be concluded that there is a power of capitalism behind the production process and commodification of children in Idola Cilik program, because everything is marketing and advertising oriented. The commercials acquired are highly dependent on the rating or ranking of the aired program. A high rating program will certainly attract interest of advertisers to promote their products and services. The commercial world is identical with money, Noor [16] since the measure of success for advertisers is how far the commercials can increase demand and money. Similar to the concept of M-C-M (money- commoditiesmore money), capitalism based on the instrumental rationality maximizes profits and production systematically and consistently, leading to a market structure that "silences" the media that do not follow the rules of the market. Therefore, it aims to accumulate similar programs and balance the other programs at the same time. In the context of Idola Cilik program, the flooding supporters will become a commodity to be traded by television to the advertisers for a nominal amount. According to Ardono, fetish value takes place when money becomes the primary measure in a triangular relationship of media (television), advertisers and public. Commodities contain fetish value (amulet). An 
object has fetish value if it is considered to have the absolute value of daily life for the viewers. Thus, it makes sense that the behavior of the viewers often refers to the television 'demand'. On the other hand, the viewers are actually a fetish value for the media industry. The media turns the viewers into a selling commodity in the interest of the capital accumulation. Rating is necessarily becomes the main reference marking the position of event in media. High or low rating automatically becomes a talisman for media managers to determine the value of commodities of the program, meaning the proper fee of the space for commercials.

According to the dynamics of capitalism, the relation among the public, viewers and media runs in the scope of "public commodity". The loss of identity, alienation, and ignorance, of which norms hold, cause people to be easily affected by the media. Media become a means of identity provider, provide a friend, display interpretations of events, indirectly lead public in decision-making, provide satisfaction of human needs of entertainment and affect the way of thinking. In this context, it is necessary to be wary of the bad consequences of media in the context of maintaining the purity of children's soul. The performance of children delivered in the form of entertainment often makes the entertainment itself, not the submitted values, as the primary substance. Television is an agent of popular culture, so that it can produce a variety of luxury or joy to heterogeneous society because of the characteristics of the text and the ability of its acceptance is the active participation in the production process called "culture". As a popular culture, the content of television programs is determined by economic power. It tends to be homogeneous and the content itself is the most important thing. Popular culture is a mass culture produced through mass production industry techniques and commercialized to gain profits from public consumer. The mass culture is determined by profits of production and commercials produced by potential mass marketing. Idola Cilik program is one of the expressions of popular culture designed by television industry in order to meet the needs of society for entertainment, because a real genre of variety show can affect public perception that what they watch can also happen to them. The various kinds of talent shows on television can not only entertain but also be perceived by the common society as an easy way to be an idol in an instant way. Commodification is encouraged and created by the television industry because the television itself is an expression of materialistic society. Television is a cultural agent and commodity. It produces the meanings that serves the dominant interest in society and distributes the meanings among different social groups. The structure of the society nowadays is determined by the market, and commodification becomes legal. Everything is traded and controlled by market mechanisms. Commodification is formed from classes forming capitalism and capital becomes the dominant tools to control. The class with dominance and capital can make everything in the material production as a commodity. In Idola Cilik program, media industry (RCTI) is the dominant class that makes capital as a means of controlling the subordinate classes, namely the children and the viewers. Subordinate classes become the material in program production created by the production team (media workers) as a commodity. The commodity is then sold by the media-company or industry to advertisers. Practically, the society spends most of their time to consume a number of advertising messages that eventually affect or persuade them to spend money in order to buy commercialized products. It makes a triangular relation among media, viewers and advertisers. However, if the television program acts only as a supporting instrument of the advertisers, it only aims to give the advantage to the advertisers instead of the viewers; whereas, the television industry frequently suggests programs oriented on viewers.

Based on the aforementioned explanation, it can be concluded through the following Figure 2 that the background of Idola Cilik program production, is a product of popular culture (mass culture) and a practice of capitalism on the singing contest program: 


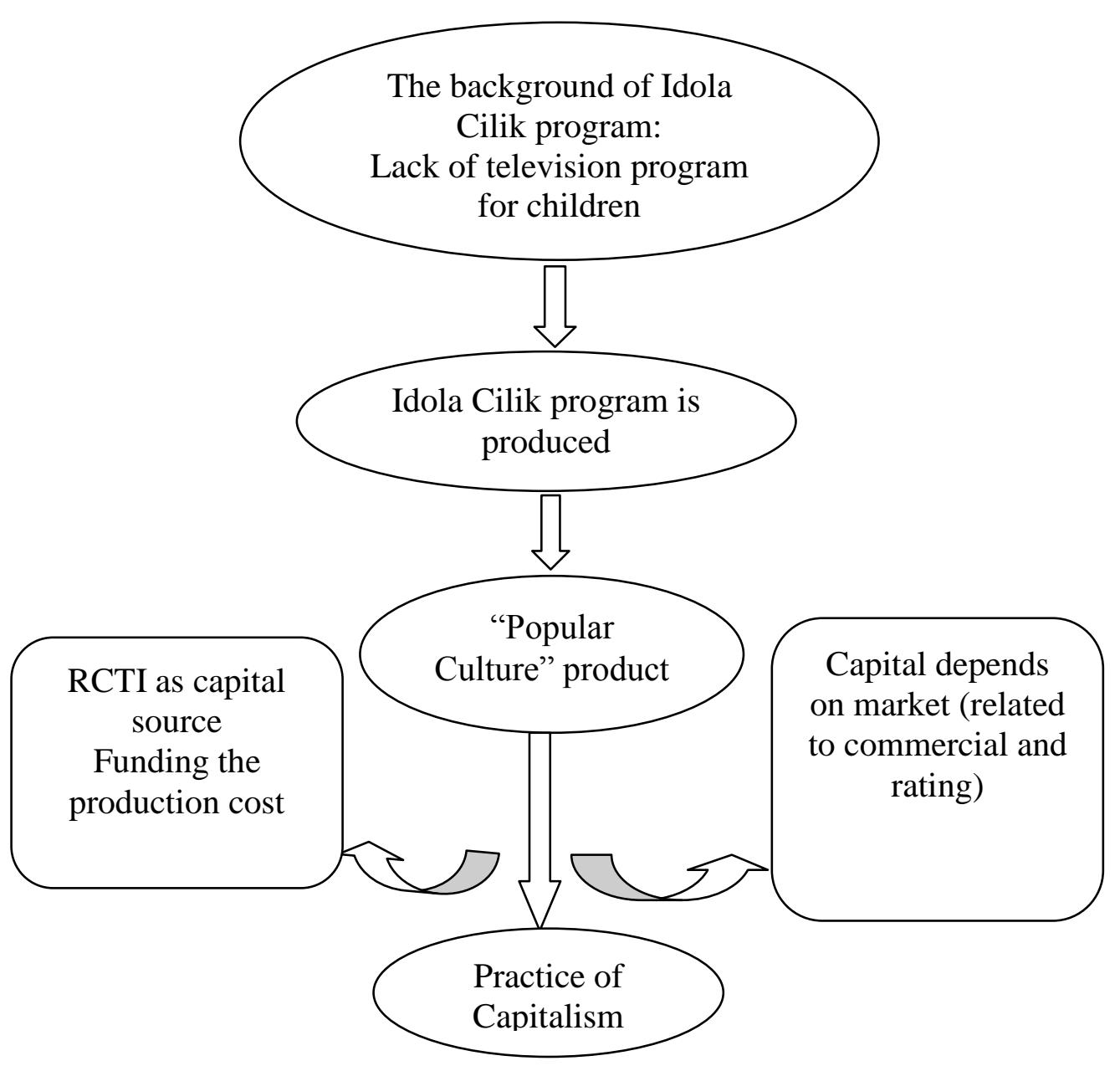

Figure 2. A social Cognition of Idola Cilik Program

Based on Figure 2 above, on the background of the production, the result of social cognition of the producer of Idola Cilik is the lack of programs for children. According to the author, it is incorrect because the television program is produced for the benefit of the media themselves, specifically in relation to the political economy of the media. It is because political economy is directed to the ownership, control and operational power of the media market. From this standpoint, the mass media institutions are regarded as an economic system that is closely linked to the political system.

The main character of a political economy approach is the production of media that is determined by the exchange of diverse media content, under the pressure of market expansion and determined by the political economy of capital owners and policy makers of media. Thus, in fact, Idola Cilik program is produced not only for the political economy of media, but it also shows the obvious practice of capitalism in the television industry, particularly private television (RCTI). This program earns money, showing the cultural value, far exceeds the production cost by showing commercials and SMS voting by the viewers to support their idol. Children's media not only become a channel of popular culture where the parents construct the identity of completely ideal childhood, but the children also understand their childhood with their needs as children. Thus, the children's media are the pop culture. The popular culture eventually referred to as commodity culture is produced on a large scale, based solely on economic benefits and economic ability to get prestige instead of moral teachings, until it gives bad influence for public because of good or bad assessment. In addition, the products of popular culture will damage elite culture and the nature of system of manners in social life. Therefore, the capitalist changes the form of the capital from money into commodity. By operating 
facilities and raw materials the labor generates a new commodity whose value belongs to the capitalist. In Idola Cilik program, the media workers produce the program into a use value in the form of talent's distribution and development and increase of children's potential through the singing contest. Then, the results are submitted to the television media (RCTI), then sold to the advertisers and public in the form of exchange value. The exchange value will affect the rating. The more the viewers watch the program, the more the commercials are aired. Automatically, the program will get high rating. In the realization, television media gain more profit from the issued capital. Under capitalism, everything that can generate profits for the owners of production group will be treated as a commodity. After television evolves into a cultural industry, consequently, it has to face the generated market. Television is a capitalist business, a tool of social control, as well as a source of popular enjoyment. The phenomenon of television partly exemplifies the idea that society is driven by the interests of the capital owners and economic power. Commercial television is funded by a capitalistic system. Based on the analysis of social context, according to the Chairman of National Commission on Children Protection, Seto Mulyadi, it can be interpreted that sometimes the television industry and the parents do not realize that they exploit the children through entertainment world in television. When there is an element of instruction and psychological pressure, it is already called an exploitation and abuse of children's rights, such as Idola Cilik singing contest in one of the television stations, RCTI. These children appear with thick makeup, dress like adults, endure more than three hours of broadcast, and sing an adult song required by the producer. Parent's reason for developing their children's talents should not reduce the rights of children as stated in Law Number 23 of 2002. It is because, during that period, the children still need parental guidance both in playing and learning. Besides, the phenomenon of children become young idols has to consider the psychological state of the children, because the children are still in the stage of searching for identity and forming attitude. The point is, these children are still in the development stage. Children gradually get an understanding of the emotions simultaneously between the ages of 4 to 12 years, as they move through five levels of development Papalia and Feldman [17]. Emotional, self-concept and psychosocial development of children at any level are clearly different, since they are influenced by time and environmental conditions, where, when, with whom, and under what circumstances they interact. However, children who focus on the field of entertainment seem as if they do not receive talent development, or if they do, it is just a little, because what stands out is that they work as an idol and they get payment for what they do. What television industry does as a medium to transfer the positive values regarding the children who follow this singing contest becomes vague since they only show the children as commodities and with or without their realization, they are the main characters of the Idola Cilik program. The children consciously follow the program with a dream that they can be the winner. Nevertheless, they do not realize that they are just instruments played by media in order to get more profits. It is merely for the benefit of the television and the parents, not the children; whereas, children have the right to be able to play happily without pressure or coercion. In accordance with the children's rights, Article 10 of Law Number 23 of 2002 on Child Protection stipulates that "Every child has the right to rest and relax, to get along with their friends, to play, to go on recreation, and be creative in accordance with their interests, talents, and the level of intelligence for selfdevelopment". The author assumes that Idola Cilik program is closely related to the protection of children's rights, children's psychological development, and suitable concept of program for children, exploration and revival of classic children's songs and traditional songs, fulfillment of specific standard program for children, the parents' awareness in choosing program suitable with children's age development and commodification of children. RCTI TV station is asked to review all relations regarding those issues. Based on the aforementioned social context analysis, Idola Cilik program is interpreted negatively rather than positively. Instead of developing children's potential 
and talent, it turns out that the program has hidden aspects of capitalism and commodification of television industry. Based on the aforementioned description, the interpretations of Idola Cilik program can be summarized in Figure 3 as follows:

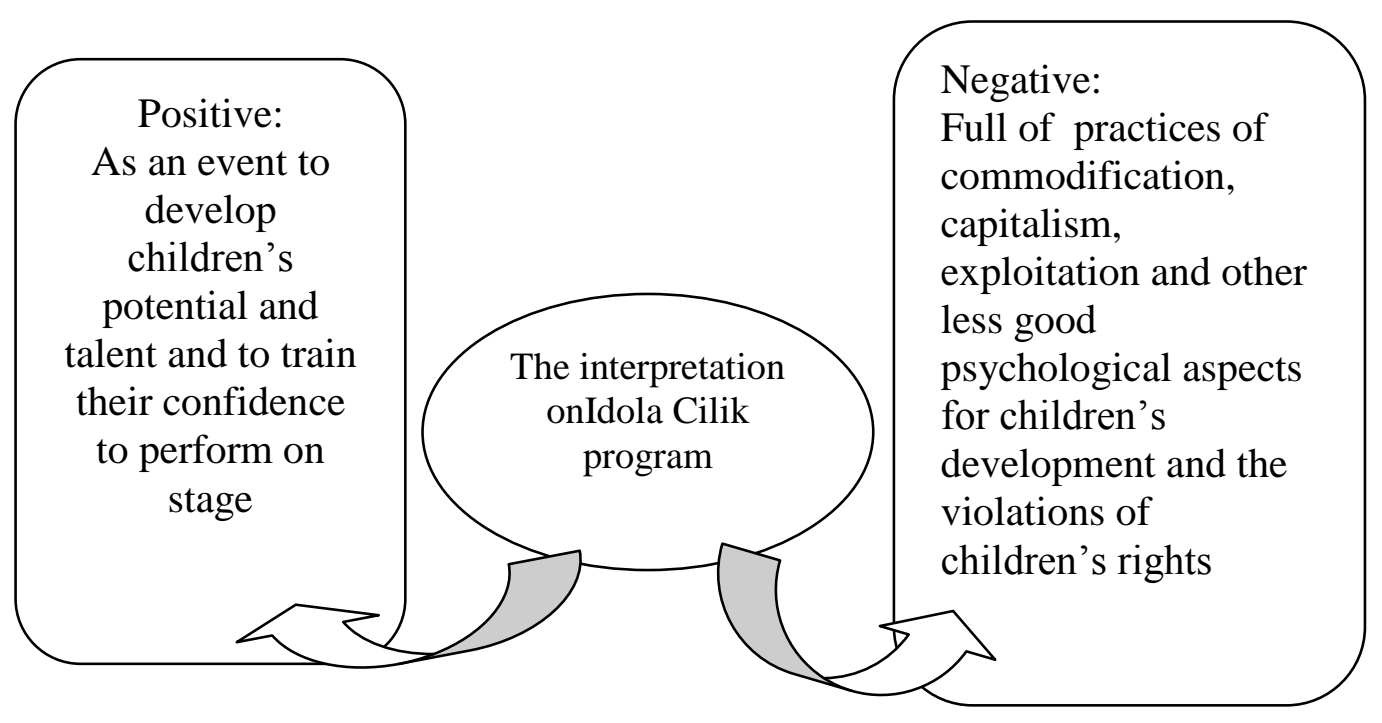

Figure 3. Interpretations of Idola Cilik Program

The Idola Cilik program receives positive and negative assessment from the society. However, the negative assessment is more dominant because it is considered inappropriate for children due to many reasons, such as costume, make up, song theme, choreography, broadcast hours, etc. This leads to serious consequences for psychological development of the children, the exploitation of children, and violation of the children's rights and violation of fulfillment of the standards of specific program for children. Ideally, the children are given lessons and chances to develop naturally in accordance with their potential and talent without coercion from any party, particularly from the parents through the media. Children should be seen as a precious asset of a nation in the future, whose rights should be kept and protected, for in their hands, the development of nation is determined.

Therefore, through this study, the producers of programs for children are expected to be more concerned about the compatibility of program contents, and to pay much attention to the psychology of children, by putting the children not merely as some commodity to gain huge profit. As for the parents, they should be more selective on choosing TV programs for their children. Moreover, the parents are also advised not to exploit their children by forcing them to be TV stars.

\section{Conclusion}

The results showed (1) Based on the analysis of the text, the performance and the commodification of children in Idola Cilik program are actually the result of television media industry as a business institution (RCTI). It has become a commodity, to be bought and sold, and controlled by market mechanisms, through a program's rating, that it ultimately is profit-oriented. (2) Based on the analysis of social cognition, RCTI's Idola Cilik program is created due to the lack of special programs for children. "Idola Cilik" is a popular culture with instant characteristics and is a market oriented program. The practice of capitalism is seen in the television industry, although RCTI, as a capitalist, is trying to show that exploitation does not happen by creating a number of provisions for the sake of achieving their interests, making it looks as if it is not them who commodify the children. (3) Based on the analysis of social context, "Idola Cilik" has generated positive 
interpretation. The program can be a means of developing children's talent and potential in accordance with their characteristics. There is also a negative interpretation that the program is a form of commodification of children, leading to potential exploitation and violation of children's rights.

\section{Acknowledgement}

This research is supported by University of Prof. Dr. Moestopo (Beragama), Jakarta, Indonesia.

\section{References}

[1] T. Evens and K. Donders, "Mergers and acquisitions in TV broadcasting and distribution: Challenges for competition, industrial and media policy", Telematics and Informatics, vol. 33, (2016), pp. 674-682.

[2] J. Oh, S. Kim, J. Kim, and H. Yu, "When to recommend: A new issue on TV show recommendation", Information Sciences, vol. 280, (2014), pp. 261-274.

[3] A. Ansari and R. Crosnoe, "Children's hyperactivity, television viewing, and the potential for child effects", Children and Youth Services Review, vol. 61, (2016), pp. 135-140.

[4] H. Li, K. Boguszewski, and A. S. Lillard, "Can that really happen? Children's knowledge about the reality status of fantastical events in television", Journal of experimental child psychology, vol. 139, (2015), pp. 99-114.

[5] L.-Y. Lin, R.-J. Cherng, Y.-J. Chen, Y.-J. Chen, and H.-M. Yang, "Effects of television exposure on developmental skills among young children", Infant behavior and development, vol. 38, (2015), pp. 2026.

[6] P. Murphy, "Design Capitalism: Design, Economics and Innovation in the Auto-Industrial Age", She Ji: The Journal of Design, Economics, and Innovation, (2015).

[7] K. J. Renner, T'he'evil Child'in Literature, Film and Popular Culture: Routledge", (2013).

[8] M. Michalis and P. Smith, "The relation between content providers and distributors: Lessons from the regulation of television distribution in the United Kingdom", Telematics and Informatics, vol. 33, (2016), pp. 665-673.

[9] K. Dunsmore and K. C. Haspel, "Bringing class to light and life: A case study of reality-based television discourse", Discourse, Context \& Media, vol. 6, (2014), pp. 45-53.

[10] T. Evens and K. Donders, "Television distribution: economic dimensions, emerging policies", Telematics and Informatics, vol. 33, (2016), pp. 661-664.

[11] C. Gordon, "Impression management on reality TV: Emotion in parental accounts", Journal of Pragmatics, vol. 43, (2011), pp. 3551-3564.

[12] Eriyanto, "Analisis wacana: pengantar analisis teks media: LKiS Yogyakarta", (2001).

[13] S. D. Gunarsa, "Dari anak sampai usia lanjut: bunga rampai psikologi anak: BPK Gunung Mulia", (2004).

[14] S. Sunarto and T. Rahardjo, “Analisa discourse: ideologi gender media anak-anak oleh”, (2000).

[15] V. Mosco, "The political economy of communication: Rethinking and renewal", vol. 13, (1996).

[16] H. F. Noor, "Ekonomi Media", (2010).

[17] D. E. Papalia, S. W. Olds, and R. D. Feldman, "Human development (Psikologi perkembangan edisi kesembilan)", Jakarta: Kencana, (2008). 
International Journal of $\mathrm{u}-$ and $\mathrm{e}-$ Service, Science and Technology Vol.10, No.6 (2017) 